\title{
The activity of acyl CoA: retinol acyltransferase in the rat: variation with vitamin A status
}

\author{
By MAGNHILD RASMUSSEN, LIZETTE B. PETERSEN \\ AND KAARE R. NORUM \\ Institute for Nutrition Research, School of Medicine, University of Oslo, PO Box 1046, \\ Blindern, Oslo 3, Norway
}

(Received 11 April 1983 - Accepted 13 September 1983)

1. Retinol esterification in the small intestine, liver and kidney of rats given a normal diet or a vitamin-A-free diet and of rats given large doses of vitamin $\mathbf{A}$ was studied. The active enzyme is a microsomal acyl CoA:retinol acyl transferase (ARAT).

2. In the small intestine ARAT activity was $0.37 \mathrm{nmol}$ ester $/ \mathrm{mg}$ microsomal protein per min. Large doses of vitamin $\mathrm{A}$ increased the activity significantly, while the enzyme activity in the vitamin-A-deficient rats was in the range of that of the controls. Retinoic acid in physiological doses $(0.064 \mathrm{mg}$ three times per week) had no influence on ARAT activity.

3. In the liver, ARAT activity of the controls was $0.58 \mathrm{nmol}$ ester $/ \mathrm{mg}$ microsomal protein per min. The activity was increased after large doses of vitamin A. It was not significantly reduced in vitamin-A-deficient animals.

4. The kidney had a low, but significant ARAT activity, both in normal and vitamin-A-deficient animals and after large doses of vitamin A (range $0.08-0.14 \mathrm{nmol}$ ester $/ \mathrm{mg}$ microsomal protein per min).

5. The vitamin-A-esterifying enzyme in the small intestine and liver of the rat seems to be influenced by the amount of retinol in the diet.

The main dietary sources of vitamin $\mathrm{A}$ are $\beta$-carotene and esterified retinol. Retinyl esters are hydrolysed in the intestinal lumen before absorption (Mahadevan et al. 1963a,b) and $\beta$-carotene is converted into retinol in the wall of the gut (Olson, 1961 ; Goodman \& Huang, 1965). Esterification takes place in the intestinal mucosa (Goodman, 1980), catalysed by a microsomal acyl CoA : retinol acyltransferase (ARAT; Helgerud et al. 1982, 1983). Retinol is transported from the intestine as retinyl esters in association with chylomicrons (Huang \& Goodman, 1965). Retinol esterification by an acyl CoA transferase also takes place in the liver (Ross, 1982a), mammary gland (Ross, 1982 b) and kidney (Donoghue et al. 1981).

Intestinal ARAT has several properties in common with intestinal acyl CoA: cholesterol actyltransferase (ACAT; EC 2.3 . 1.26): they are both microsomal acyltransferases and, in rats, their specific activity is approximately the same. They have the same $\mathrm{pH}$ optimum and both are inhibited by the thiol blocking agent 5,5'-dithiobis(2-nitrobenzoic acid) and by the detergent taurocholate. Fasting increases the activity of both enzymes (Helgerud et al. 1982). Norum et al. (1983) have shown that the activities of ACAT and ARAT are higher in intestinal mucosal villous cells, which are active in lipid absorption, than in the crypt cells. ACAT activity in both small intestinal mucosa (Norum et al. 1977, 1983; Drevon et al. 1979) and in liver (Norum et al. 1983) increase on feeding a diet rich in cholesterol.

The aim of the present study was to determine whether the vitamin A status of the rat affected retinol esterification in the gut and liver. Some rats were given a vitamin-A-free diet, others received large doses of retinol. The effect of retinoic acid was tested. ARAT activity of the kidney was determined. 


\section{EXPERIMENT AL}

\section{Materials and methods}

Chemicals. $\left[1-{ }^{3} \mathrm{H}(N)\right] \mathrm{retinol}$ (all trans) with specific activity $14 \cdot 3 \mathrm{Ci} / \mathrm{mmol}$ was purchased from New England Nuclear, Boston, MA. It was dissolved in ethanol and stored in the dark under nitrogen at $-20^{\circ}$. Retinol (all trans) was purchased from Sigma Chemical Co., St Louis, MO. The cold retinol was dissolved and stored in the same way as the radioactive vitamin. Radioactive and cold retinol were mixed to give a specific activity of approximately 20-30 $\mu \mathrm{Ci} / \mu \mathrm{mol}$. The concentration was calculated on the basis of the absorbance measured at $328 \mathrm{~nm}$, using $\mathrm{E}_{1}^{1 \% \mathrm{~m}} 1780$ (Wolf, 1980) with a Cary spectrophotometer (Varian Associates, Inc., Palo Alto, CA). This stock solution was kept under the same conditions as described previously for cold and radioactive retinol. It was tested for purity by controlling the absorption spectrum (Cama et al. 1952; Moore, 1957a) and by alumina column chromatography as described on p. 247 . Less than $0.5 \%$ of the radioactivity was eluted in the retinyl ester fraction.

Palmitoyl-CoA, bovine serum albumin (essentially fatty acid free), dithiothreitol and dimethylsulphoxide were obtained from Sigma Chemical Co. $N N^{\prime}$-Diphenyl-p-phenylenediamine was obtained from Eastman Kodak Co., Rochester, NY.

All other chemicals used were of standard commercial high purity.

Diets. The control diet was the Swedish vitamin-A-free diet (see below) with the addition of vitamin A $(3.6 \mathrm{mg} / \mathrm{kg})$ or a standard pelleted normal diet for rats, purchased from Moellesentralen, Oslo, containing $2.7 \mathrm{mg}$ vitamin $\mathrm{A} / \mathrm{kg}$.

The vitamin-A-free diets were obtained from Nutritional Biochemicals, Cleveland, Ohio or from EWOS A/B, Södertälje, Sweden. The diets were mainly composed of starch, vitamin-A-free casein and vegetable oil with the addition of salts and vitamins, except vitamin A.

Vitamin supplements. Two types of retinol supplements were used: one containing $6.9 \mathrm{mg}$ retinol (as retinyl palmitate)/ml vegetable oil (AFI-A Diagnosticum; A/S Farmaceutisk Industri, Oslo), the other containing $240 \mathrm{mg}$ retinol (as retinyl palmitate) $/ \mathrm{ml}$ vegetable oil (Hoffman-La Roche \& Co. Ltd, Basel).

Retinoic acid (all trans) (Sigma Chemical Co.) was (unless stated otherwise) dissolved in ethanol $(10 \mathrm{mg} / \mathrm{ml})$ and kept at $-20^{\circ}$ in the dark. Every $7-10 \mathrm{~d} 0.175 \mathrm{ml}$ of this solution was added to $2 \mathrm{ml}$ groundnut oil. The latter was supplemented with $\alpha$-tocopherol and menadione (Lamb et al. 1974). A small volume of diethyl ether (about $0.35 \mathrm{ml}$ ) was added to dissolve the retinoic acid. All vitamin supplements were given orally.

Animals. Male rats of the Wistar strain were purchased from Dyrlæge Möllegaard Hansen, Avlslab A/S, Ejby, DK 4623 L1 Skensved, Denmark. The feeding regimens for the different groups of animals are shown in Table 1. They had free access to food and water and were maintained at a controlled temperature $\left(21-26^{\circ}\right)$ and relative humidity $(50-65 \%)$. They had $12 \mathrm{~h}$ light during the daytime.

The animals on the vitamin-A-free diet were given this diet from about 3 weeks of age. They were then housed in steel-wire cages, one to two animals per cage. Their weight increased steadily up to 8 weeks on the diet, when a plateau was reached at about $310 \mathrm{~g}$ (255-355 g) for the animals not receiving retinoic acid. 'Levelling off' in weight is an early sign of vitamin A deficiency (Moore, 1957b; Wolf, 1980). We have shown that when the weight plateau is reached, the rats have less than $1.0 \mu \mathrm{g}$ retinol $/ \mathrm{g}$ liver. The young control rats had liver stores of vitamin A of the order of $150 \mu \mathrm{g} / \mathrm{g}$ liver.

After 9 weeks on the diet, some of the rats had a slightly unsteady gait and their fur began to look unkempt.

The rats were killed in the morning after having fasted $16 \mathrm{~h}$. The proximal one-third of 
Table 1. Feeding regimens of the different groups of rats

\begin{tabular}{|c|c|c|c|}
\hline $\begin{array}{l}\text { Group } \\
\text { no. }\end{array}$ & Diet & $\begin{array}{l}\text { Duration of } \\
\text { dietary } \\
\text { treatment } \\
\text { (weeks) }\end{array}$ & Additions \\
\hline 1 & Control ) & & None \\
\hline 2 & Control & $\begin{array}{l}\text { Fed } \\
\text { continuously }\end{array}$ & $\begin{array}{l}\text { Retinyl palmitate, } 1 \mathrm{mg} \text {, given over the } \\
\text { last } 3 \mathrm{~d}\end{array}$ \\
\hline 3 & Control & $\begin{array}{l}\text { throughout the } \\
\text { experimental }\end{array}$ & $\begin{array}{l}\text { Retinyl palmitate, } 17 \mathrm{mg} \text {, given over the } \\
\text { last } 2 \mathrm{~d}\end{array}$ \\
\hline 4 & Control & period & $\begin{array}{l}\text { Retinoic acid, } 0.064 \mathrm{mg} \text {, three times per week } \\
\text { for the last } 4 \text { weeks }\end{array}$ \\
\hline 5 & Vitamin-A-free & $3-4$ & None \\
\hline 6 & Vitamin-A-free & $8-9$ & None \\
\hline 7 & Vitamin-A-free & 9 & $\begin{array}{l}\text { Retinyl palmitate, } 1.7 \mathrm{mg} \text {, the day before } \\
\text { killed }\end{array}$ \\
\hline 8 & Vitamin-A-free & 8 & $\begin{array}{l}\text { Retinoic acid, } 0.064 \mathrm{mg} \text {, three times per week } \\
\text { for the last } 4 \text { weeks }\end{array}$ \\
\hline
\end{tabular}

the jejunum was removed, its mucosa scraped off and microsomes prepared as described by Helgerud et al. (1982). Liver and kidney microsomes were prepared in the same way.

The organs were removed on ice, and the prepared microsomes were stored at $-70^{\circ}$ if more than 1 week elapsed before they were tested, otherwise they were stored at $-20^{\circ}$.

Assay for testing ARAT activity. ARAT was assayed by measuring the formation of labelled retinyl ester after incubating radioactive retinol with unlabelled palmitoyl-CoA. The assay conditions were basically the same as those described by Helgerud et al. (1982), although modified after Ross (1982a), so that radioactive retinol from the stock solution (see p. 246) was dried under $\mathbf{N}$ and redissolved in dimethylsulphoxide.

In preliminary experiments we found the optimal concentrations for palmitoyl-CoA, bovine serum albumin and microsomal protein in small intestine to be the same as those reported by Helgerud et al. (1982), and the reaction was linear with time up to $10 \mathrm{~min}$. The optimal concentration of retinol, however, was higher when the retinol was dissolved in dimethylsulphoxide.

Incubations were performed in glass extraction-tubes at $37^{\circ}$. Incubation volume was $250 \mu \mathrm{l}$ and the medium contained (final concentration in $0.2 \mathrm{M}$-potassium phosphate buffer, pH 7.4): palmitoyl-CoA $20 \mu \mathrm{M}$, bovine serum albumin $14 \mu \mathrm{M}$, dithiothreitol $5 \mathrm{mM}, N N^{\prime}$ diphenyl-p-phenylenediamine $0.12 \mathrm{~mm}$. After preincubating in a shaking water-bath for $5 \mathrm{~min}$, about $75 \mu \mathrm{g}$ microsomal protein was added, and after $50 \mathrm{~s}$ the incubation was started by adding $\left[{ }^{3} \mathrm{H}\right] \mathrm{retinol}$ in $5 \mu \mathrm{l}$ dimethylsulphoxide to a final $\left[{ }^{3} \mathrm{H}\right]$ retinol concentration of $80 \mu \mathrm{M}$. Incubation was stopped after $5 \mathrm{~min}$ by adding $5 \mathrm{ml}$ chloroform-methanol $(2: 1, \mathrm{v} / \mathrm{v})$.

The incubation conditions used for intestinal microsomes were suitable for microsomes from liver and kidney.

Each microsomal preparation was tested in duplicate. The blank consisted of microsomes boiled for $1 \mathrm{~min}$.

After extracting the lipids according to Folch et al. (1957), the chloroform phase was evaporated under $\mathbf{N}$. The residue was dissolved in a small volume of hexane, and retinyl ester was separated from retinol by alumina column chromatography using a two-step elution with 1:50 and 1:1 (v/v) of diethyl ether-hexane respectively (Helgerud et al. 1982). The radioactivity in each fraction was determined quantitatively using a Packard Tri-Carb liquid-scintillation spectrometer, and the label in the ester fraction was expressed as a 
percentage of the total radioactivity recovered in the ester + retinol fractions. The resulting ester produced was expressed as nmol formed $/ \mathrm{mg}$ microsomal protein per min and was the mean value from duplicate determinations. The radioactivity recovered in the ester fraction of the blank was consistently lower than $0.75 \%$. Over-all recovery of added radioactivity was generally in the range $60-100 \%$.

The procedures were carried out under dim light until the ester was separated from the unreacted retinol.

Vitamin A analysis

Retinol in liver homogenate was determined by high performance liquid chromatography after hydrolysis and extraction modified after Bieri et al. (1979) and Ross (1981). Serum samples were not saponified unless stated otherwise, so that retinyl esters, if present, would give rise to distinct peaks on the chromatogram. These peaks could then be compared with external retinyl ester standards.

\section{Chemical analysis}

The protein determination was according to Lowry et al. (1951), using bovine serum albumin as a standard.

\section{Statistics}

Statistically significant differences between groups were determined by Wilcoxon's rank sum test, which is resistant to deviations from the probability distribution (Hodges \& Lehmann, 1964).

\section{RESULTS}

\section{Small intestine}

The ARAT activity of small intestinal mucosa is shown in Table 2 . When rats were given large doses of vitamin $A$ in the last few days before they were killed, the ARAT activity rose significantly. The response seemed to be dose related: the activity increased more with $17 \mathrm{mg}$ retinyl palmitate (group 3 ) than with $1 \mathrm{mg}$ retinyl palmitate (group 2).

The mean esterification rate of the vitamin-A-deficient animals was in the same range as that of the controls after 4 weeks on the diet (group 5) and after 8-9 weeks on the diet (group 6). Thus even totally-retinol-depleted animals were able to esterify vitamin $\mathrm{A}$ at the same rate as the controls and, like the latter, the deficient rats also had a significantly increased esterification rate in response to large doses of dietary vitamin A.

Retinoic acid is known to fulfil the functions of retinol in the body, except those associated with vision and reproduction (Wolf, 1980), and animals receiving retinoic acid will increase in weight normally on a vitamin-A-free diet (Lamb et al. 1974). In the present study retinoic acid was administered in the diet in the last 4 weeks, both to rats given the control diet (group 4) and to rats given the vitamin-A-free diet (group 8). Retinoic acid did not significantly change the ARAT activity in these two groups of rats compared with controls.

Table 3 shows the liver vitamin A concentrations in rats given retinoic acid orally, $0.064 \mathrm{mg}$ in approximately $0.25 \mathrm{ml}$ ethanol three times per week for the last 4 weeks. It appears that retinoic acid did not significantly change the liver's store of vitamin $\mathrm{A}$, and the serum retinol level was in the same range as that for the controls. The rats used just for this part of the study were older and their average weight was higher than the animals used in the rest of the study. We think this is the reason why their liver content of vitamin A was relatively high. 
Table 2. Acyl CoA:retinol acyltransferase (ARAT) activity in microsomes from rat small intestinal mucosa

(Values for enzyme activities are means and standard deviations for each group, for duplicate determinations for each rat within the group)

\begin{tabular}{|c|c|c|c|c|}
\hline & \multirow{2}{*}{$\begin{array}{c}\text { Group } \\
\text { no. }\end{array}$} & \multirow{2}{*}{$\begin{array}{c}\text { No. of } \\
\text { rats }\end{array}$} & \multicolumn{2}{|c|}{$\begin{array}{c}\text { ARAT activity } \\
\text { (nmol retinyl ester } \\
\text { formed/mg protein } \\
\text { per min) }\end{array}$} \\
\hline & & & Mean & SD \\
\hline Controls & 1 & 4 & 0.37 & 0.20 \\
\hline Control diet, extra retinyl palmitate $(1 \mathrm{mg})$ & 2 & 3 & $0.67 * \dagger$ & $0 \cdot 10$ \\
\hline Control diet, extra retinyl palmitate $(17 \mathrm{mg})$ & 3 & 3 & $1 \cdot 23 \ddagger$ & 0.24 \\
\hline Control diet, extra retinoic acid & 4 & 3 & 0.26 & $0 \cdot 10$ \\
\hline Vitamin-A-deficient 4 weeks & 5 & 4 & 0.41 & $0 \cdot 18$ \\
\hline Vitamin-A-deficient $8-9$ weeks & 6 & 8 & $0 \cdot 36$ & $0 \cdot 17$ \\
\hline $\begin{array}{l}\text { Vitamin-A-deficient } 9 \text { weeks, extra retinyl } \\
\text { palmitate }\end{array}$ & 7 & 4 & $0.57 \S$ & $0 \cdot 13$ \\
\hline Vitamin-A-deficient 8 weeks, extra retinoic acid & 8 & 3 & $0 \cdot 31$ & 0.13 \\
\hline
\end{tabular}

The animals were grouped and given different diets and vitamin supplements according to Table 1. For details of animals and their diets, see p. 246. For details of incubation procedures, see p. 247.

Statistical significance was determined by Wilcoxon's rank sum test.

- $P<0.005$, group $2+3 v$. group 1 .

$\dagger P<0.05$, group $2 v$ group 1 .

$\ddagger P<0.05$, group $3 v$ group 2 .

$\S P<0.05$, group $7 v$. group 6.

Table 3. Vitamin $A$ levels in rat liver and serum. The effect of feeding retinoic acid

(Values for vitamin $\mathrm{A}$ are means and standard deviations for each group, for duplicate determinations for each rat within the group)

\begin{tabular}{|c|c|c|c|c|c|}
\hline & \multirow{2}{*}{$\begin{array}{l}\text { No. of } \\
\text { rats }\end{array}$} & \multicolumn{2}{|c|}{$\begin{array}{l}\text { Total retinol } \\
(\mu \mathrm{g} / \mathrm{g} \text { liver })\end{array}$} & \multicolumn{2}{|c|}{$\begin{array}{c}\text { Retinol } \\
(\mu \mathrm{g} / 1 \text { serum })\end{array}$} \\
\hline & & Mean & SD & Mean & SD \\
\hline Controls & 3 & 331 & 19 & 326 & 15 \\
\hline $\begin{array}{l}\text { Control diet, } \\
\text { extra retinoic acid }\end{array}$ & 3 & $296^{*}$ & 49 & $315^{*}$ & 36 \\
\hline
\end{tabular}

The test group received retinoic acid orally, $0.064 \mathrm{mg}$ in approximately $0.25 \mathrm{ml}$ ethanol three times per week for the last 4 weeks. All animals in this table were given the control diet.

The liver samples were saponified, see p. 248.

Statistical significance was determined by Wilcoxon's rank sum test.

* Not significant, test group $v$. controls.

\section{Liver}

The ARAT activity of liver microsomes is shown in Table 4.

The enzyme activity was significantly increased $(P<0.02)$ when the rats received large doses of vitamin A.

In the vitamin-A-deficient rats the ARAT activity tended to be lower than that in the controls, although not significantly so $(P<0 \cdot 10)$. 


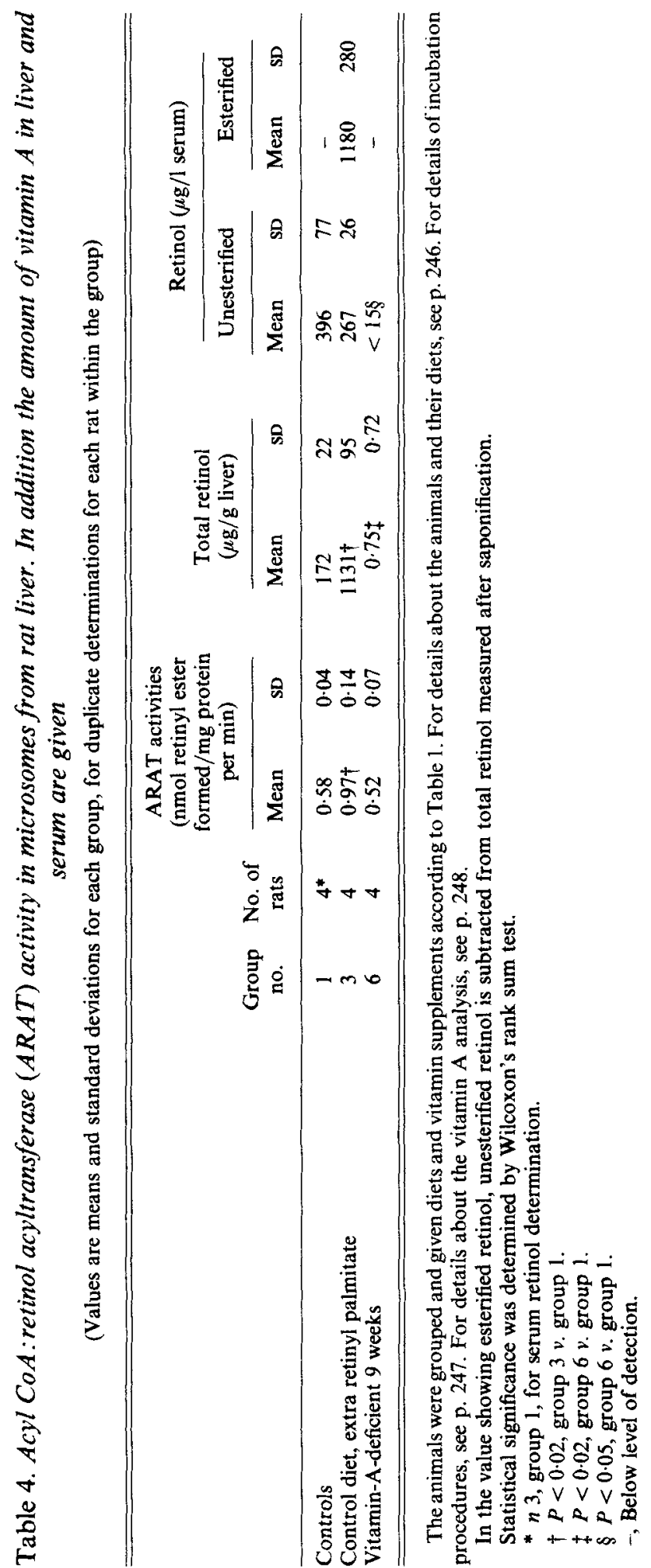


Thus variations in vitamin A status affected retinol esterification rate in essentially the same way in small intestinal and liver microsomes.

Table 4 also demontrates that the vitamin A content of the liver changed significantly in response to the different amounts of vitamin A fed. In rats on the control diet we found values of around $170 \mu \mathrm{g}$ retinol/g liver, which are normally found. Rats given a vitaminA-free diet for 9 weeks had $<1 \mu \mathrm{g} / \mathrm{g}$, whereas rats given large doses of vitamin $\mathrm{A}$ had in excess of $1000 \mu \mathrm{g}$ retinol/g liver.

The serum level of the vitamin-A-deficient rats was significantly reduced (Table 4), while the level of free retinol did not increase after large doses of vitamin A. The retinyl ester found in blood from the animals fed on high doses of vitamin A corresponded mainly to palmitate and stearate.

\section{Kidney}

ARAT activity in normal rat kidney was $0.12(\mathrm{sD} 0.015) \mathrm{nmol}$ ester formed $/ \mathrm{mg}$ microsomal protein per $\min (n 4)$. The esterification rate was in the same range $(0.08-0.14 \mathrm{nmol} / \mathrm{mg}$ protein per $\mathrm{min}$ ) for animals receiving large doses of vitamin A and for vitamin-A-deficient animals. Thus the ARAT activity of rat kidney was considerably lower than that in the small intestine and liver, and the activity in the kidney did not change with the vitamin A status of the rat.

\section{DISCUSSION}

In the present study we determined the activity of ARAT in the microsomal fraction of intestinal mucosa, liver and kidney from rats given different amounts of retinol and retinoic acid, in order to establish whether the vitamin A status of the animals had any influence on enzyme activity (a variation in retinol esterification may suggest a physiological role for ARAT).

In the intestine, ARAT activity was increased significantly on feeding a diet containing high levels of retinol for only 2-3d, and the response seemed to be related to the retinol level. The increased activity was not due to an increased amount of retinol in the incubation assay, as the microsomes contained only small amounts of the vitamin (M. Rasmussen, unpublished results). Furthermore, the activity was not decreased in animals depleted of vitamin A due to a retinol-free diet. It is not surprising, therefore, that both normally-fed animals and animals depleted of retinol had normal ARAT activity in the intestinal mucosa after they were given physiological doses of retinoic acid. Feeding $1.7 \mathrm{mg}$ retinol to the vitamin-A-depleted animals $1 \mathrm{~d}$ before they were killed increased the ARAT activity to the same extent as in the normally-fed animals. The increase in ARAT activity produced by feeding retinol may have been even larger than that observed in the present study as the vitamin was fed together with vegetable oil which has been reported to apparently decrease intestinal ARAT activity (Norum et al. 1983).

ARAT activity is low in crypt cells and high in villous cells (Norum et al. 1983), suggesting an increase in activity during the differentiation of the crypt cells into absorptive villous cells. Whether the increased ARAT activity associated with retinol feeding was the result of increased enzyme production or only activation of the existing enzyme cannot be established from our findings. However, ARAT formation was not dependent on retinol. ARAT activity is probably important for the animal, as vitamin A is an essential nutrient which may not always be present in the food of free-living animals.

Like Ross (1982a) we found that rat liver microsomes catalysed retinol esterification. ARAT activity in liver was, as in the intestine, increased in the presence of excess dietary retinol and did not significantly decrease in vitamin-A-depleted rats. We have only studied the microsomal fraction of total liver homogenate, and this may not be the best way to evaluate the physiological role of ARAT in the liver. The different liver cells most probably 
have different roles in vitamin A metabolism. The retinyl esters of the chylomicron remnants derived from intestinal mucosa are taken up in the liver parenchymal cells but are, to a certain extent, stored in non-parenchymal cells in normally-fed rats (Blomhoff et al. 1982). In vitamin-A-depleted animals, however, newly-absorbed retinol is not transferred to non-parenchymal cells from parenchymal cells (Blomhoff et al. 1982). Since retinol is stored mainly as retinyl ester, most of the variation in ARAT activity associated with differences in vitamin A feeding will probably be found in the fraction of non-parenchymal cells which store vitamin A. A technique has been developed (Bøyum et al. 1983) for separating the non-parenchymal cells into almost homogenous populations of endothelial cells, macrophages and stellate cells. ARAT activities in these different cell populations, both from normally-fed animals and animals given large doses of vitamin A or no vitamin A are presently under investigation.

The kidney is probably important in vitamin A metabolism (Vahlqvist, 1972; Peterson et al. 1973; Glover et al. 1974). A substantial amount of newly-absorbed vitamin A is taken up by the kidney in normally-fed rats (Goodman et al. 1965). Furthermore, rats on a vitamin-A-free diet seem to have increased vitamin $\mathbf{A}$ in the kidneys as compared to rats on a normal diet (High, 1954; Nakano \& Morita, 1982). These findings prompted us to determine ARAT activity in kidney microsomes. The activity we found was much lower than that in liver and small intestine but in the same range as that reported by Donoghue et al. (1981). Both the low ARAT activity in the normally-fed rats and the lack of variation with vitamin A status suggest that esterification of retinol is not of major importance in vitamin A metabolism in rat kidney.

In conclusion, we have demonstrated ARAT activity in microsomes of rat small intestinal mucosa and liver, activities which varied with the vitamin A status of the animals. These observations give further support to the view that ARAT is of physiological importance in vitamin A metabolism.

The study was supported by grants from the Norwegian Cancer Society and the Anders Jahre Foundation. M.R. is a Fellow of the Norwegian Cancer Society.

\section{REFERENCES}

Bieri, J. G., Tolliver, T. J. \& Catignani, G. L. (1979). American Journal of Clinical Nutrition 32, $2143-2149$.

Blomhoff, R., Helgerud, P., Rasmussen, M., Berg, T. \& Norum, K. R. (1982). Proceedings of the National Academy of Sciences, USA 79, 7326-7330.

Bøyum, A., Berg, T. \& Blomhoff, R. (1983). In Biological Separations in Iodinated Density Gradient Media, pp. 147-174. [D. Rickwood, editor]. London: Information Retrieval Ltd.

Cama, H. R., Collins, F. D. \& Morton, R. A. (1952). Biochemical Journal 50, 48-60.

Donoghue, S., Johnson, K., Donawich, W. J. \& Sklan, D. (1981). Journal of Dairy Science 64, $2419-2421$.

Drevon, C. A., Lilljeqvist, A. C., Schreiner, B. \& Norum, K. R. (1979). Atherosclerosis 34, 207-219.

Folch, J., Lees, M. \& Sloane Stanley, G. H. (1957). Journal of Biological Chemistry 226, 497-509.

Glover, J., Jay, C. \& White, G. H. (1974). In Vitamins and Hormones. Advances in Research and Applications, vol.

32, pp. 224-232. [R. S. Harris, P. L. Munson, E. Diczfalusy and J. Glover, editors]. New York: Academic Press.

Goodman, DeW. S. (1980). Federation Proceedings 39, 2716-2722.

Goodman, DeW. S. \& Huang, H. S. (1965). Science 149, 879-880.

Goodman, DeW. S., Huang, H. S. \& Shiratori, T. (1965). Journal of Lipid Research 6, 390-396.

Helgerud, P., Petersen, L. B. \& Norum, K. R. (1982). Journal of Lipid Research 23, 609-618.

Helgerud, P., Petersen, L. B. \& Norum, K. R. (1983). Journal of Clinical Investigation 71, 747-753.

High, H. G. (1954). Archives of Biochemistry and Biophysics 49, 19-29.

Hodges, J. L. Jr \& Lehmann, E. L. (1964). Basic Concepts of Probability and Statistics, pp. 303-311. San Francisco: Holden-Day Inc.

Huang, H. S. \& Goodman, DeW. S. (1965). Journal of Biological Chemistry 240, 2839-2844.

Lamb, A. J., Apiwatanatorn, P. \& Olson, J. A. (1974). Journal of Nutrition 104, 1140-1148.

Lowry, O. H., Rosenbrough, N. J., Farr, A. L. \& Randall, R. J. (1951). Journal of Biological Chemistry 193, $265-275$.

Mahadevan, S., Seshadri Sastry, P. \& Ganguly, J. (1963a). Biochemical Journal 88, 531-534.

Mahadevan, S., Seshadri Sastry, P. \& Ganguly, J. (1963b). Biochemical Journal 88, 534-539. 
Moore, T. (1957a). Vitamin A, pp. 42-50. Amsterdam: Elsevier Publishing Company.

Moore, T. (1957b). Vitamin A, pp. 34-38. Amsterdam: Elsevier Publishing Company.

Nakano, K. \& Morita, A. (1982). British Journal of Nutrition 47, 645-652.

Norum, K. R., Lilljeqvist, A. C. \& Drevon, C. A. (1977). Scandinavian Journal of Gastroenterology 12, $281-288$.

Norum, K. R., Helgerud, P., Petersen, L. B., Groot, P. H. E. \& de Jonge, H. R. (1983). Biochimica et Biophysica Acta 751, 153-161.

Olson, J. A. (1961). Journal of Biological Chemistry 236, 349-356.

Peterson, P. A., Rask, L., Östberg, L., Anderson, L., Kamwendo, F. \& Pertoft, H. (1973). Journal of Biological Chemistry 248, 4009-4022.

Ross, A. C. (1981). Analytical Biochemistry 115, 324-330.

Ross, A. C. (1982a). Journal of Biological Chemistry 257, 2453-2459.

Ross, A. C. (1982 b). Journal of Lipid Research 23, 133-144.

Vahlqvist, A. (1972). Scandinavian Journal of Clinical and Labortory Investigation 30, 349-360.

Wolf, G. (1980). In Human Nutrition, vol. 3B, pp. 97-203. [R. B. Alfin-Slater and D. Kritchevsky, editors]. New York: Plenum Press. 